\section{PP-081＼cjkstart新入生向けプログラム参加前後での 環境への適応 2}

○村 文香 ${ }^{1}$

(1東京家政学院大学)

キーワード: 大学生, フレッシュマンイベント, プログラム開発

入学者の特性の多様化に伴い, 新入生の入学前後には工夫をこらした 導入教育が行われている。一方で，このような取り組み自体が，入学者 にとっては不適応を引き起こす場となるケースも報告されている。本研 究では, 都市部のビル型キャンパスを活用した導入教育プログラムへの 参加前後での適応の実態を明らかにすることを目的とする。このプログ ラムは, 所属先や教員, 学生といった環境への適応を促進することが, 既 に明らかにされている。調查対象者は，Z 女子大学 $\mathrm{Y}$ 学科の全新入生で あり，質問紙調查をプログラムの実施前後に行った。有効回答数は113て あった。クラスメイトや学科といった, 学生にとって近い環境について は，プログラム前の愛着がプログラム後の愛着と関連を持つことが示さ れた。それ以外の「授業開始への期待」「教員への親しみ」,「学部への 愛着」,「大学への愛着」については, プログラム前からのポジティブ感 情とは関わりなく, プログラムによって変化させやすい可能性が示唆さ れた。

連絡先 E-mail：fumicak.cocolo@gmail.com

\section{PP-083大学生における持続的な無気力の検 討一無気力に対する認識と感情の変 化に着目して一}

○林 雅子

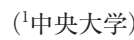

キーワード：無気力，認識と感情のズレ，縦断調査

大学生の持続した無気力に対する認識と感情の変化を検討する為に， 3 回にわたる縦断調查を行い，関東圈内の大学生121名（男性13名, 女性108 名, 平均年齢18.86歳, $S D=0.82)$ が参加した。授業に対する無気力に ついてクラスター分析を行い，意欲が持続的にある群，やや高い無気力 傾向が持続している群，平均的な群と持続的に高い無気力傾向を示して いる群にわけた。

分散分析の結果, 持続的に無気力傾向が高い群は, 自分自身の将来や 他者との関わりに対する無気力など，他のことに対しても無気力である と認識していた。一方で，1，2 回目の調查では自分が無気力であるこ とに焦りや不安はあまり見られず，他者に対する心のゆとりも，意欲の ある群とほとんど差は無かった。つまり，自身が無気力であることに対 する認識と感情にズレが生じていた。

しかし, 2 回目から 3 回目の調查にかけて, 学業に対する無気力や日々 の生活に対する疲れなど, 比較的程度の軽い無気力にも範囲が広がり, 自 身が無気力であることの焦りや不安が高まり，他者に対する心のゆとり も見られなくなることが示唆された。無気力状態が長引くにつれ，感情 とのズレが無くなっていくと明らかにされた。 会うのか一

○石黒 広昭

(立教大学)

キーワード : 芸術体験, 幼児, 遊び

本研究では，見なれない芸術作品が周庭に置かれた子どもたちが，と のようにふるまうのか，また，その作品を含む遊び環境をどのように再 組織化するのか調查し，その芸術体験の質を検討した。通常，外遊びで は自然物が持つ誘発性が强調されることが多いが，本研究では，造形物 に触発された子どもたちの創造活動の特徵について子備的調查を行った。 調查協力者として, 幼稚園の年長児15名が, 同園の教諭とともに二日間 放課後に参加した。美術家が創作した二種の金属造形物と調査者が木の 間に張り巡らせた紐が事前に設定され，そこで子どもたちを含む全参加 者が一切制限なく, 自由に遊んだ。これらの様子は, 定置ビデオ, 移動 カメラ (GoPro)，スチールカメラによって記録され，各日終了後には， 参加した大人全員でふり返りのミーティングを行った。その結果，子と もたちは芸術作品の表象する世界観に直接応答することはなく，自分た ちが馿染んだ遊び形態にそれらを取り入れていたようであった。他方，素 材特性に対する応答性は極めて高く，オリジナル作品を作る子どももい た。

連絡先 E-mail：ishiguro@rikkyo.ac.jp

\section{PP-084＼cjkstart教員を志望する大学生の自己像と理 想の教師像一ビッグファイブ次元に よる検討一}

○関塚 麻由

('秀明大学)

キーワード : 理想の教師像, 教員志望大学生, ビッグファイブ

本研究の第一の目的は, 教員を志望する大学生の自己像と理想の教師 像の特徵を明らかにすることであった。また第二の目的は，男子大学生 と女子大学生の特徽の違いを検討することであった。そのため, 小中高 等学校の教員を志望する大学生114名（男性72名, 女性42名) を対象に, ビッグファイブ理論で用いられる，外向性，協調性，勤勉性，神経症傾 向, 開放性の各次元から 4 項目ずつ合計20項目について, 自己像と理想 の教師像の調查を実施した。その結果，すべての次元，項目において，自 己像と理想の教師像との間に有意差が認められた。また，自己像と理想 の教師像の相関分析では，協調性の次元で正の相関がみられ，項目別で は「人のためになろうとする」「思いやりがある」「誠実な」「協調性があ る」「社交好き」「明るい」の項目で, 自己像と理想の教師像との間に低 い正の相関が認められた。男女の比較をしたところ，自己像の外向性の 次元は女性が男性よりも得点が高かった。また，理想の教師像の「論理 的な」は男性が女性よりも高かった。調查対象者は，大学入学時から教 員になることを強く志望する学生であり，教員の資質能力に対する高い 理想を持っていることが示された。 